\title{
Financial logistics innovations in IT Project Management
}

\author{
Igor Ilin ${ }^{1, *}$, Olga Kalinina ${ }^{1}$, and Sergei Barykin $^{2}$ \\ ${ }^{1}$ Peter the Great St.Petersburg Polytechnic University, Polytechnicheskaya, 29, St. Petersburg, \\ 195251, Russia \\ ${ }^{2}$ Selectel Ltd., Head of Internal Audit, Ul. Tsvetochnaya 21, lit. A, St. Petersburg, 196084, Russia
}

\begin{abstract}
The article covers the Financial Logistics methodology implementation to management of complex IT projects. The Methodological logistics unit is a new field of research in the field of a new type of scientific rationality based on the humanistic dimension in the globalization era. The article describes the approach to the scientific development of the cognitive system of a society based on the individualization of demand and consumption in the conditions of the online economy
\end{abstract}

\section{Introduction}

Revolutionary development of information technologies has caused constant growth of investments into this sphere. The majority of developing companies make significant part of their capital investments in IT projects [1-5]. Therefore, it is necessary to improve IT project management and to promote economic methods for enhancement of operating efficiency.

\section{Methodology}

In the accordance with the latest methodological approach to management could be referred to financial logistics innovations in the sphere of combined logistical and IT systems as to the point of view of Bennet T. McCallum and Marvin S. Goodfriend the transactions should spend time [16] and in reliance with Orazio Attanasio, Luigi Guiso, Tullio Jappelli) [17] both would be taken into the account the technological innovations and the duration of transactions being made.

The improvement of classical logistical approach to finances is based on the critical papers by Sprenkle (regarding the disadvantages of transactions demand models) [18], Meltzer (considering the demand for money in relation to business firms») [19], Morris (discussing the transactions demand for cash) [20] and Grace (examining the specification of the cost function in Baumol's and on Morris' transactions demand for cash) [21]. As far as IT is concerned IT project management means management of project implementation process. Project implementation, in its turn, means a package of measures to be taken to achieve project goals. Yield increase and company value maximization are the priority goals of IT projects implemented by trading companies. Economic results included in the original plan

\footnotetext{
*Corresponding author: ivi2475@gmail.com
} 
may be significantly altered during project implementation process depending on evolving circumstances and obtained interim results. Therefore, project implementation should be regarded as a continuous process which requires regular analysis of the current situation and trends. Such analysis may result in necessary adjustments. The authors suggest a system of financial and economic calculations in order to solve this problem. This system consists of three types of calculations which need to be made regularly and consistently during the project implementation process:

a) commercial evaluation of projects and business planning;

b) financial diagnostics of the companies which implement projects;

c) business valuation at different project phases.

Projects are classified using various criteria, such as application area, subject field, scope, length, types of participants, complexity, impact of results on social sphere etc. [6-8].

Depending on the scope and structure projects are divided into mono-projects, multiprojects and mega-projects. Multi-projects are complex programmes and projects implemented within big companies. Such projects include both establishment of new companies and development of existing ones, as well as corporate management modernization. This paper is dedicated to economic and financial calculations for IT multiprojects, i.e. projects aimed at establishment of new IT companies or branches of existing IT companies. The suggested calculation system provides for their effective development and creates conditions for operational management and decision-making at different phases. It should be noted that there are quite a lot of classifications of large-scale project phases $[6,8$, $10]$.

The authors use classification which divides a project into four phases:

1) pre-opening arrangements, initial financing and organizational development (start-up);

2) fast sales growth, significant investments in production, optional negative cash flow;

3) substantial economic results, return on investments, positive cash flow;

4) loss of income due to escalating competition, search for new ideas and development scenarios, optional negative cash flow.

Specific financial and economic calculations will ensure successful project implementation at each phase.

Feasibility study comprising commercial evaluation of projects and business planning is applicable at the first stage.

Regular assessment of a company's financial position and control over achievement of financial and economic goals set in its business plan is expected at the second stage.

Control over a company's financial position and business valuation are performed the third stage in order to prepare for the fourth stage.

Another business valuation, development of new ideas and business planning are done at the fourth stage.

Calculation methods should be based on decision-making criteria at each phase in order to achieve successful project management and rational decision-making (Table 1).

Initial decisions are made based on the project feasibility study and business planning. A business plan is a list of works and activities structured by sections which are required for project implementation. In this context a project is an investment plan aimed at achievement of intended benefits. A business plan is prepared in order to provide rationale for project costs and, consequently, for its financing sources. The business plan is one of the principal documents to be submitted to investors and creditors. Business plans were originally prepared only for investment projects. That is why costs and resulting income should be calculated and justified for all works and activities included in the document. Based on these calculations investors and creditors make a decision on whether to finance the project or not. 
Table 1. Project phases and financial and economic calculation methods.

\begin{tabular}{|l|l|l|}
\hline \multicolumn{1}{|c|}{ Multi-project phases } & Financial and economic calculation methods & $\begin{array}{l}\text { Decision-making } \\
\text { criteria }\end{array}$ \\
\hline $\begin{array}{l}\text { 1 Pre-opening } \\
\text { arrangements, initial } \\
\text { financing }\end{array}$ & Feasibility study and business planning & $\begin{array}{l}\text { Net present value, } \\
\text { profitability and } \\
\text { operating leverage }\end{array}$ \\
\hline $\begin{array}{l}\text { 2 Fast sales growth, } \\
\text { optional negative cash } \\
\text { flow }\end{array}$ & $\begin{array}{l}\text { Regular assessment of a company's financial } \\
\text { position and control over achievement of } \\
\text { goals set in its business plan }\end{array}$ & $\begin{array}{l}\text { Special system of } \\
\text { financial indicators }\end{array}$ \\
\hline $\begin{array}{l}\text { 3 Return on } \\
\text { investments, positive } \\
\text { cash flow }\end{array}$ & $\begin{array}{l}\text { Control over a company's financial position } \\
\text { and business valuation }\end{array}$ & $\begin{array}{l}\text { System of financial } \\
\text { indicators, company } \\
\text { value }\end{array}$ \\
\hline $\begin{array}{l}\text { 4 Escalating } \\
\text { competition, search for } \\
\text { new ideas and } \\
\text { development scenarios }\end{array}$ & $\begin{array}{l}\text { Another business valuation, development of } \\
\text { new ideas and business planning }\end{array}$ & $\begin{array}{l}\text { Company value, } \\
\text { profitability and } \\
\text { operating leverage }\end{array}$ \\
\hline
\end{tabular}

As multi-projects started to evolve, this calculation system turned out to be flawed due to the fact that above mentioned decision-making criteria were not applicable to describe business efficiency. Financial position of a company and its development effectiveness are characterized by efficiency and solvency indicators. Among the most important indicators there are return on sales, return on assets and return on equity, as well as such solvency indicators as equity-to-asset ratio, financial leverage, current ratio, quick ratio and solvency ratio. In order to ensure efficient multi-project management, it is necessary to combine these indicators which are different for projects and businesses in one business planning system. Having performed multiple studies and calculations, the authors recommend the following two approaches to economic assessment of IT multi-projects:

a) two-step financial and economic calculations for investment projects;

b) one-step calculations for operational projects.

The methodology suggested by the authors to evaluate investment projects using the first approach is based on the UNIDO method [9] and provides for two-step calculation [11-14];

Step 1: efficiency evaluation based on calculation of profitability and discounted indicators;

Step2: assessment of project implementation impact on the increase in profit, labour efficiency, profitability and operational risks.

The company's planning system is presented in the Fig. 1.

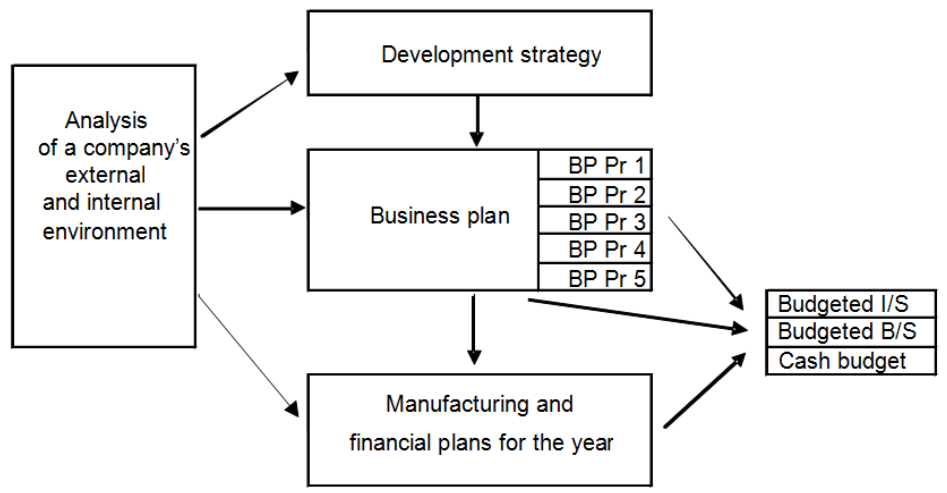

Fig. 1. General planning system at an IT company, compiled by the authors. 
In such a way business planning performed at the first phase of an IT multi-project is naturally incorporated in the general planning system of a company due to the fact that development project business plans and company business plans are elaborated according to accepted company strategies. While current (annual, quarterly) plans for trading and manufacturing activities are based on approved business plans.

\section{Financial logistics innovations in IT Project Management}

Business planning is a part of the general planning system of a company. It is based on a strategy development and used for current annual and quarterly planning. In order to evaluate specific projects such approach requires preparation of three documents which are usually disregarded when a usual project business plan is prepared. These documents include a budgeted income statement prepared using a standard income statement template, a budgeted balance sheet prepared using a standard balance sheet template and a cash budget prepared using a standard cash flow statement template which could be consolidated with respective statements. These documents make it possible to evaluate how implementation of each project will affect financial position of the company under consideration, its profitability and solvency, as well as manufacturing and commercial risks. The main financial and economic indicators used to characterize budgeted results at both steps of multi-project evaluation are listed below.

Step 1. Efficiency evaluation based on calculation of profitability and discounted indicators: payback period, simple rate of return, net present value, internal rate of return.

Step 2. Assessment of project implementation impact on the increase in profit, labour efficiency, profitability and operational risks. increase in sales profit, performance improvement (sales per one employee per month), return on sales, operating leverage.

It should be noted that the list of indicators for the second step may be significantly extended depending on the specific nature of each company which implements a multiproject. Additional indicators are selected using the financial diagnostics method developed by the authors within economic and financial calculations for IT multi-projects [10].

Calculation results based on a business plan of a big telecommunications company of the Siberian Federal Okrug are presented in Table 2. Only payback period is included in the table from resulting (criterial) indicators of the first step.

Table 2. Economic evaluation using the two-step calculation system.

\begin{tabular}{|l|c|c|}
\hline \multicolumn{1}{|c|}{ Project types } & $\begin{array}{c}\text { Special mobile } \\
\text { Internet 1 }\end{array}$ & $\begin{array}{c}\text { Special mobile } \\
\text { Internet 5 }\end{array}$ \\
\hline Number of users, thousand people & 50 & 75 \\
\hline Number of employees, people & 12 & 8 \\
\hline Investments, million rubles & 157.0 & 120.0 \\
\hline Sales, million rubles / year & 120.000 & 58.00 \\
\hline $\begin{array}{l}\text { Current expenses (cost), million rubles / year, } \\
\text { including : } \\
\begin{array}{l}\text { Variable expenses } \\
\text { Fixed expenses }\end{array}\end{array}$ & 69.0 & 36.0 \\
\hline Payback period, years & 48.3 & 26.5 \\
\hline $\begin{array}{l}\text { Sales profit (budgeted increase for a company on } \\
\text { the whole), million rubles / year }\end{array}$ & 3.08 & 3.75 \\
\hline $\begin{array}{l}\text { Performance improvement (number of sales per } \\
\text { person per month) \%\% }\end{array}$ & 51.0 & 32.0 \\
\hline Increase in return on sales, \%\% & 11.3 & 5.1 \\
\hline Operating leverage for a company on the whole & 5.6 & 3.2 \\
\hline
\end{tabular}


A special financial diagnostics is performed at the second and third phases in order to ensure successful implementation of IT investment projects. It has been developed by the authors and described in [10]. Its purpose is to trace changes in sales profit, net profit, profitability and return on assets, as well as risk level and solvency at the second and third project phases.

\section{Example of Financial diagnostics}

Equipment upgrade, automation or start-up of new production projects in existing company can significantly affect the structure and the cost of capital, shares of fixed and variable expenses in total expenses and cash flows. Regular control over financial position of a company makes it possible to take timely reasonable measures for successful implementation of multi-projects.

Financial diagnostics is based on:

- Quarterly calculations;

- List of financial and economic indicators in line with those set in business planning methodology;

- Comparison of actual figures of the quarter with established standards, figures of the previous quarters and business plan figures;

- Decision-making methods (strategies) in case of significant variance between actual figures and figures for comparison.

Business valuation methodology to be used at the third and fourth phases of IT multiprojects is described below. Company value maximization has been one of the most common goals of financial management and, therefore, business efficiency criteria for the last $20-25$ years. It makes it possible for owners to make more sound decisions on company sale according to the early exit strategy or on multi-project investment at the third and fourth phases in order to compensate for losses from evolving competition and decrease in sales according to the leadership strategy. In view of this, the main purpose of regular business valuation during multi-project management is to identify a moment when the value starts to decrease, to understand the reasons for that and to make timely decisions on further project implementation. The value of listed companies which have gone through IPO is determined on a daily basis, which forms a good statistics for decision-making. Valuation of small and medium enterprises may be performed by professional valuation experts. Usually this is an expensive single-use procedure. An easier alternative is required to reduce costs and provide regular results. The authors thus suggest a set of rather simple valuation methods based on financial diagnostics methodology which are easily incorporated in the overall system of financial and economic calculations for multi-projects [22]. Business valuation theory suggests three approaches achieve project goals, namely cost, income and comparison approaches. Quite a lot of methods are actually used within these approaches [15]. For IT multi-projects the authors suggest business valuation based on various development scenarios and financial diagnostics results at the second and third project phases. In order to determine initial company value at the third phase of multi-project implementation, it is necessary to consider at least two development scenarios:

- The first scenario is the lack of additional investments. The project is implemented according to the goals set forth in the business plan.

- The second scenario is fund-raising using the leadership strategy. The rise in competition, commercial and financial risks, price reduction for company services are projected for the nearest period.

In both scenarios the company value as of the valuation date is determined using the cost approach after audit and financial diagnostics of the company. In order to have more information about the company value as of the valuation date it is also necessary to use such 
income approach methods as profit capitalization, 50\% of sales and fivefold sales profit. Information about the company value may be also supplemented by the information about sales of similar enterprises. Actual value is determined based on obtained results. This figure is the base for further calculation of the company value in the planning period.

Valuation of a company which implements a multi-project on production of IT equipment elements and components is presented in Table 3.

Table 3. Initial business valuation at the third phase of multi-project implementation.

\begin{tabular}{|c|c|}
\hline Valuation method & Amount, million Rubles \\
\hline Cost approach & 142 \\
Profit capitalization & 120 \\
$50 \%$ of sales & 165 \\
Fivefold sales profit & 175 \\
\hline Approved actual value & 145 \\
\hline Company value after investments into assets taking into & 190 \\
account appreciation rate & \\
\hline
\end{tabular}

When actual value of the company as of the valuation date is determined, it is necessary to set a planning period for calculation of changes in the company value. Its length depends on the type of project but cannot exceed three years. In the first development scenario calculation of changes in the company value is made based on the above mentioned income approach methods, such as profit capitalization, 50\% of sales and fivefold sales profit. Calculation is based on budgeted amounts of sales and profit for the planning period.

Net profit for the reporting period and statistics on average return on equity of the IT group of companies under consideration are used for profit capitalization method. In the second development scenario it is necessary to obtain the company value as of the date of additional investments. It is important to take into account appreciation of the company due to attraction of additional capital. Assets turnover (turnover during the year) and return on assets are used to obtain appreciation rate. When the company value as of the date of additional investments is calculated, it is necessary to calculate the company value for the planning period. Several valuation methods may be applied here. The authors recommend using venture approach and future value method. The venture approach is easier in terms of calculations but it requires construction of a cash flow diagram for determination of the future company value. Its implementation is possible with statistics of average profitability of the IT group of companies under consideration and its budgeted profitability rate. The planning period may be set in months. In this case the comparison rate should be set on a monthly basis. The comparison rate determination is a key moment of the calculation which needs special justification. The future value method provides for more detailed and difficult calculation. It is based on tables and diagrams of budgeted cash flows and takes into account provision of loans, revenues and payments of the enterprise under consideration during the planning period. Weighted average cost of capital (WACC) or actual return on assets (ROA) are used as a comparison rate here.

This calculation system makes it possible to obtain information base for specification and determination of actual and budgeted company value, adjustment of project implementation process and finding solutions for organizational, production and financial issues.

\section{Conclusion}

The main results of the research suggest the following conclusions:

1. IT project management is a complex multiple-option process consisting of four main phases. Each phase requires adjustments based on economic analysis and calculations which include: 
a) two-step commercial evaluation and business planning;

b) special financial diagnostics;

c) regular business valuation.

2. Financial diagnostics and business valuation at the second and third multi-project phases provide a wide base of financial and economic indicators used to approve and adjust operational plans for further multi-project implementation.

3. Rather simple calculation algorithms suggested by the authors and available software will make it possible to pay more attention to reliability of benchmark data for project development monitoring.

\section{References}

1. V.N. Yuryev, Scientific and technical statements SPbSPU 2(58) (2008)

2. A.V. Nyukhin, Bulletin of the Kamchatka State Technical University, 56-59 (2010)

3. G.R. Zalyaeva, Bulletin of Kazan State University 12(2), 43-48 (2009)

4. D.N. Matvienko, Omsk Scientific Bulletin 3(83), 249-251 (2009)

5. A. Marhasin, Optimization and system design of the development of mobile communication systems. Tutorial (SibGUTI, Novosibirsk, 2000)

6. A.G. Ivasenko, Project Management: Textbook (Phoenix, Rostov, 2009)

7. R. Akoff, Planning of the future corporation (Sirin, Moscow, 2002)

8. P.S. Golov, K.V. Baldin, I.I. Peredepyayev, Investment projecting (Dashkov and Co., Moscow, 2015)

9. V. Berens, P.M. Havranek, Guidelines for assessing the effectiveness of investments: translate Engl. (Interexpert, Infra, Moscow,1995)

10. A.R. Bril, L.I. Gorchakova, O.V. Kalinina, Financial and economic calculations for innovative projects of enterprise development: Textbook (SPbSPU, 2012)

11. P.L. Vilensky, V.N. Livshits, S.A. Smolyak, Evaluation of the effectiveness of investment projects: Theory and Practice (Case, Moscow, 2015)

12. N.D. Strekalova, Business planning (PETER, 2013)

13. V.A. Goremykin, Business plan, development methodology, Axis-89 (2013)

14. A.R. Brill, Business planning: tasks and cases (Publishing house of Polytechnic, SPb, 2015)

15. D. Fridman, H. Ordway, Analysis and evaluation of income-producing real estate (The Case, Moscow, 1997)

16. T.B. McCallum, M.S. Goodfriend, In The New Palgrave: a Dictionary of Economics I, 775-781 (1987)

17. O.P. Attanasio, L. Guiso, T. Jappelli, Journal of Political Economy 110(2), 317-351 (2002)

18. C.M. Sprenkle, Journal of finance, 835-847 (1969)

19. A.H. Meltzer, Quarterly journal of economics, 405-421 (1963)

20. R.D. Morris, Quarterly journal of economics, 546-547 (1971)

21. H.S. Jr. Grace, Quarterly journal of economics, 658-659 (1975)

22. A. Burmistrov, M. Siniavina, O. Iliashenko, E3S Web of Conferences 33 (2018) doi:10.1051/e3sconf/2018330300 